\title{
Effect of Sn Loading on the Characteristics of Pt Electrocatalysts Supported on Reduced Graphene Oxide for Application as Direct Ethanol Fuel Cell Anode
}

\author{
Guilherme L. Cordeiro ${ }^{1, *}$, Valter Ussui ${ }^{1}$, Nildemar A. Messias ${ }^{1}$, Ricardo M. Piasentin ${ }^{2}$, \\ Nelson B. de Limal, Almir O. Neto ${ }^{2}$, Dolores R. R. Lazar ${ }^{1}$ \\ ${ }^{1}$ Materials Science and Technology Center, Energy and Nuclear Research Institute, National Nuclear \\ Energy Comission (IPEN-CNEN/SP), Lineu Prestes Avenue, 2242 - Zip Code: 05508-000 - São \\ Paulo, Brazil \\ ${ }^{2}$ Fuel Cells and Hydrogen Center, Energy and Nuclear Research Institute, National Nuclear Energy \\ Comission (IPEN-CNEN/SP), Lineu Prestes Avenue, 2242 - Zip Code: 05508-000 - São Paulo, Brazil \\ *E-mail: gcordeiro@usp.br
}

doi: $10.20964 / 2017.05 .68$

Received: 15 February 2017 / Accepted: 4 March 2017 / Published: 12 April 2017

\begin{abstract}
The effect of Sn loading (5-30 mol \%) on Pt catalysts supported on reduced graphene oxide was investigated for ethanol electro-oxidation in acidic medium. Reduced graphene oxide was synthesized via graphite oxidation-exfoliation process in liquid phase and chemical reduction. $\mathrm{Pt}$ and $\mathrm{Pt}_{x} \mathrm{Sn}_{y}$ catalysts were deposited on reduced graphene oxide by a $\mathrm{NaBH}_{4}$ impregnation-reduction method. The adopted procedures allowed the synthesis of graphene-like nanosheets where single Sn-doped Pt nanoparticles were impregnated. Pt lattice parameter and micro-strain increased with Sn addition, confirming the formation of a solid solution. Concerning ethanol electro-oxidation, $\mathrm{Pt}$ was more active when supported on reduced graphene oxide whereas the introduction of Sn enhanced the catalyst activity, leading to lower ethanol oxidation potentials and higher current densities.
\end{abstract}

Keywords: reduced graphene oxide, platinum, tin, ethanol electro-oxidation

\section{$\underline{\text { FULL TEXT }}$}

(C) 2017 The Authors. Published by ESG (www.electrochemsci.org). This article is an open access article distributed under the terms and conditions of the Creative Commons Attribution license (http://creativecommons.org/licenses/by/4.0/). 